\title{
Dress Rehearsal
}

$\mathrm{F}$ OR MORE THAN forty years The Secret Book of Edmund Lester Pearson has been, for all I know, very secret indeed, but at the outset of subjecting you to this ordeal I propose, for your discomfort, to exhume two passages from it. In the first, a character named Pratt (presumably Enoch Pratt) interrupts his dictation to exclaim to his secretary:

You wouldn't have me make a new and original statement at a meeting of librarians, would you? That would never do! Part of them would denounce me as flippant, and the rest-the library magazines, for instance-would refer condescendingly to what I said as "clever," which means "smart but shallow." The great art of a library meeting speech ... is to utter as many solemn platitudes as possible with a very solemn face. It is always sure to be called both "scholarly" and "sound."

You may be sure that I will follow Mr. Pratt's excellent and immutable counsel.

The second extract is a single line, found among the k's in the index, reading: "Kilts, Not Worn by Bibliographers, 25." Why this entry was made I cannot say with any assurance, but I can say quite positively that it leads to nowhere; it is a snare, a delusion, a fraud, the veriest fake. No such reference appears in the text. Of course, Mr. Pearson may have compiled the index before he wrote the book, and, thereby, have permitted his fancy to wander a little aimlessly; but a more satisfactory explanation, it seems to me, would be a conviction on the part of that stern New

Mr. Mearns is assistant librarian, American Collections, Library of Congress.
England author that only the lecherous would be so reckless, so uncomplaining, so free of self-consciousness and embarrassment, so remote from decency and refinement as to feel impelled to look up kilts - even (shall we say?) in an index.

But for me the line has a deeper meaning: it is an acknowledgment of the professional preoccupation with costume which is a trait, a guild-mark of librarians at every season and in every clime. Yet here the women have all the better of it. Listen as they protest to William Allen Butler that they have Nothing to Wear except Hawthorne's Birthmark and Miss Millay's Few Figs from Thistles. With Walt Whitman they can Sing the Body Electric and disguise Cabell's Figures of Earth by calling on William Miln to stuff them All in a Bustle. Milady has only to reach for one of Amy Lowell's Patterns to emerge as Gershwin's Rhapsody in Blue, with Hergesheimer's Bright Shawl across her shoulders, her hair bewitching with Amelia Barr's Bow of Yellow Ribbon and flashing Vincent Sheean's Pieces of a Fan. If she finds her Leather-Stocking unbecoming she can do without it altogether and let W. D. Steele cry out How Beautiful with Shoes! Even millinery is provided. She takes Michael Arlen's Green Hat, trims it with Lawrence Stalling's Plumes, and ties it on with one of Huneker's or Maugham's Painted Veils.

The men, as I say, have been less favored. The Knickerbocker's History have not only been completed; they have passed from fashion. Moreover, it is clumsy to mop an anguished brow with nothing softer than Cooper's Autobiography of a Pocket Handkerchief; Walter Scott has supplied a single Redgauntlet; 
Thomas Hood has come up with nothing more substantial than a Song of the Shirt, and so, choice must be made between Buchan's Greenmantle and Melville's White Jacket. There is no variety in neckwear; Thomas Nelson Page once found an Old Gentleman with the Black Stock, but Conan Doyle has had to relinquish His Last Bow. The severest discomfort is caused by thrusting Gilbert Parker's Seats of the Mighty into John Hay's Little Breeches. Only the elect can get about Under the Red Robe, as tailored by Stanley Weyman.

Yes, librarians have clothes all about them, yet, strangely, they have never produced a satisfactory working garb. This is not to say that they haven't tried; of course they have. Why, as long ago as 1890 , one of them named H. J. Dennis wrote a discursive letter on the subject to the Library Bureau, the following portions of which were published in the October number of The Library Journal:

I have a suggestion to make. The catalogue sent gives a long list of very useful aids ... . to the librarian, but does not mention one that I daily need, viz., a library coat, or toga, or tunic, or gown, or robe. We all know that he is well dressed whose garb is adapted to his work, whether he is about to make a balloon ascension or go down into the bottom of the deep in a diving-bell. Now, the work of a librarian is a good deal mixed, and, hence, a proper garment for him requires some thought. He starts in the morning rather neatly clad in a business suit, and at his desk and in his general work is all au fait, but soon the "antiquarian" comes in and wants some dust-covered folio exhumed from the sands of Egypt on Shelf 13. The librarian climbs the ladder and finds the volume, venerable with the dust of ages, and on climbing down with the principal part of the dust belonging to the volume removed to his own person, he is confronted by a troop of visitors to the capitol, and must be introduced all around before he can seek the relief of the dust- broom. He did not cut a very genteel figure and knows it, whereas, had he worn a proper garment, he would have been as ready to receive company after his dust-bath as before.

What should the library tunic be, and how made? My idea is, there should be one for summer and one for winter use. The summer one might be of gray silk, and the winter one of gray cassimere, light, fine, and probably lined. It should be cut loose about the shoulders and with loose sleeves; should have a neat, lowstanding collar, rounded at the corners, and fitted with a clasp emblematic of his office, say, an open book, with light frogs down the front. It should be neatly gathered over the chest, with a wide band around the waist with a clasp similar to the one at the throat, only larger, and close buttoned at the waist. The skirts should hang fully to the knee-it would be better to hang a little below. Pockets at right and left of breast and skirts with lapels over skirt pockets. The cassimere one could be made the same, except it might be lined.

Now, there is a garment, as I can see it in my fancy, that would be comfortable and becoming, and make the librarian a properly dressed man in all the departments of his work, and when at night he exchanged his robe on the peg for his "Prince Albert," to go upon the street, he would not have the appearance of just returning from a house cleaning. I have never been able to describe this garment so that a tailor could make it, and yet it seems to me that a tailor of some taste could easily do it. I believe librarians generally would want these garments if they could get them-at least I should be ready to take two of them. You might add this garment to your list of library conveniences, and it seems to me that it would not be the one least appreciated by the craft. Let your artist devise the style of the garment, and an artistic tailor furnish rules for taking the proper measure in each case, and it seems to me that the orders would begin to come in. By getting the proper goods in quantities to afford you wholesale prices, and by having many gar- 
ments made by one firm, you could supply them cheaper than they could be obtained elsewhere, to say nothing of their being more neatly and tastefully made. Why should not the librarian have a uniform, or at least a garment that is at once comfortable and adapted to his work?

Whether the Dennis smock ever gained common acceptance or attained a general vogue, I do not know, but I do know that when Herbert Putnam, a few years later, became librarian of the Boston Public he was photographed in an outfit curiously combining the features of a Salvation Army uniform with the regalia of a bellhop at the Waldorf, and with the initials $B . P$. L . embroidered on the collar in solid gold. Mr. Putnam does not appear to have persisted in wearing this costume; perhaps he found it too often mistaken for a lackey's livery rather than for the finery of a field marshal.

Our English confreres have always had an instinct for correct appearance. This is borne out by a reference in Alexander John Philip's The New Assistant; or, The Junior's Vade Mecum where, on page 17 , is the admonition: "Keep a good look out for dingy backs... or dirty edges: they are all worth further examination in the never-ending campaign to keep. . . clean and fresh and bright." But, alas, our British colleagues take a dim view of women in librarianship. Not so long ago I chanced on the following strictures which appear in Lionel McColvin's Library Staffs, published in 1939:

Women are quite capable of undertaking many, if not indeed all, types of library work; for some, such as work with children, they are much more suitable than men.

There are, however, good reasons why librarianship should not become entirely or predominantly a "woman's profession." We must consider this matter frankly and trust that no offence is given where none is intended. Firstly, it is a fact that as our world is constituted, most activities are on the whole "run" by men, and, consequently, those which are not are at some disadvantage. There are several fine and capable women in library work to serve as the exception to prove this rule, but in general, if librarianship is to take its just place as a profession, if the librarian is to claim equality of status with other chief officers, and if he is to represent the needs of the service to committees and councils which are predominantly male, the senior executive and administrative library posts should be held by men. Clearly, we cannot have men in charge unless we have men in all the subordinate grades preparing themselves to fill the higher posts of the future.

Secondly, many of the contacts and many of the duties are such that a man is more appropriate than a woman.

Thirdly, as society is at present constituted, it is the man's function, as a rule, to support a wife and family. Consequently, unless there is any reason why a particular means of earning a livelihood should be delegated to women, there are potent reasons why it should be given to men.

Fourthly, a majority of women marry and then leave work. Thus, if we were to staff our libraries entirely with women, we should lose much that is valuable; the accumulation of experience would be less, as experience would continually be draining away. Neither could we count on the same amount of initial interest and enthusiasm, for though many women undoubtedly give of their best whatever the prospect of matrimony, it would not be reasonable to expect that in the aggregate a group of women would have the same incentive as a group of men whose whole future depended on their efforts.

These arguments do not allow us to exclude all women from librarianship, but they make it clear that if women are admitted, their presence must not be prejudicial to the interests of men (and indirectly of the women those men may want to support as wives).

Now methinks these alarums of Westminster's City Librarian are un- 
chivalrous, ungallant, and unavailing, but they are, I suspect, nothing new. This frightened prejudice among the British has been going on for a long time. Otherwise, how can one explain the Worthing Staff Library Overall, which must be seen to be believed? The atrocious habit appears to have been the work of that traducer of womankind, Marion Frost, who was herself a woman presumably and a librarian presumptuous.

An illustrated article in praise of the vile creation besmirched the pages of The Library World for November, 1908; in it, the unfeeling Miss Frost wrote:

Woman's place in the work of the world has been much discussed, but few will deny that she is eminently suited to Public Library work. It is a profession which requires tact, good temper, neatness, and care for detail. These are woman's strong points in business life.

The woman librarian is, however, often lacking in that sense of fitness in dress which is essential in a position where neatness and smartness are necessary. The need for a professional dress for the woman librarian has been long felt by all who come in contact with her. At her best, even when "well-dressed" in the ordinary sense, she appears inappropriate behind the counter of a library, but at her worst she is unspeakable. Open-work blouses, trailing skirts, and imitation jewelry are appallingly unsuitable.

Efforts to alter this state of things have meant continuous pressure, even to repress the more glaring errors of dress. The policy of "pin-pricks" which this necessitates is most distasteful to any librarian, particularly if the chief be a man.

A complete reform is the only solution of the difficulty. May I give a short account of the attempt made in Worthing to deal with this problem, and the results obtained? I suggested to my staff the desirability of wearing an overall, or some kind of uniform-dress.

There were of course, objections, the chief being:
1. It was an extra expense.

2. It was unbecoming.

3. It was a uniform.

However, these objections were easily removed when I proved:

1. That the initial expense need be only a few shillings.

2. That one can be artistically as well as suitably dressed.

3. That a uniform is not synonymous with servility.

It was pointed out that the third objection was on a par with the action of the misguided domestic who removes her cap and apron when cleaning the doorstep in the deluded hope that she may be taken for the daughter of the house. There is little reason in either procedure, and as little effect. We are earning our living, and why should we be ashamed to "dress the part"? In addition to these negative points, the positive advantages were felt to be very great. There was the great convenience of being able to wear the "overall" over any kind of dress, and, when taken off, an assistant could be dressed ready to pay calls, golf, cycle, or whatever she might wish to do. And again, that if something of the kind be not soon adopted, chief librarians will insist that their staff wear black.

The staff difficulties being thus overcome, the dress itself was considered. The design was the first consideration. We wanted something that was easily put on and taken off; that did not look like a cooking apron on the one hand, or an illfitting dress on the other. After a number of experiments, the design shown in the accompanying photograph was adopted. It has received the approval of various librarians, and has proved very satisfactory. There should be little difficulty in adopting the idea in any library.

A girl starting on her business career easily assimilates ideas, and will quickly adopt a uniform costume when shown the desirability of a neat and workmanlike attire, and when given ideas of what to wear and when to wear it. Half the diffculties are overcome when you can prove to her that she will not be tied to any particular style of dress, may come to the li- 
brary dressed as she pleases, but that, when on duty, she must look official.

Tastes are so dissimilar that it is advisable to choose a dark colour for the overall. Ours is made of dark green alpaca -a material which shows neither dust nor dirt-enlivened with a buff-coloured silk braid. It is made in one and fastens down the front from the neck to twelve inches below the waist. It has a fixed belt. If made at home the cost is five shillings eleven pence. Of course, a cheaper material can be used, but it is doubtful if it is economy. Brown holland would be a good substitute, but would require constant washing.

Ladies and gentlemen, in your interest I have carefully studied that "accompanying photograph." In my unpracticed opinion the model is an abomination, resembling a voluminous "Peter Thompson" cum rickrack, topped with a whale-boned collar. It should have brought the most exquisite contumely, excoriation and contempt upon Marion Frost. It should have been consigned forthwith to a waxen figure of horrors at Madame Tussaud's. But it remained for one of those jealous males to lead the chorus of derision. This was W. George Chambers, of Plumstead, who wrote a letter to the editor, published in the very next issue of The Library World, in which he said:

Surely attempts of this kind to bring woman assistants down to the level of domestic servants and shop girls are bound to recoil upon those who make them. In these freedom-loving days, people are being allowed more and more liberty in the matter of dress, and even the immaculate frock coat and silk hat of the male, which not long ago was considered obligatory upon members of the Stock Exchange, is gradually giving way to the desire of the individual for more perfect freedom.

Gradually the anti-feminine crusade crossed the waters and penetrated to these States. In 1913, the trustees of the
Cleveland Public Library promulgated these regulations governing attire:

Dress: Simple waists, with lining or underslips of sheer materials. Sleeves below the elbows always. Neck never lower than "Dutch neck." If without collar, "V" necks or other low cuts should never be worn without a guimpe or dickey. If they come appreciably below the lower collar line, collars and ruchings should always be fresh and clean. Half-worn finery never has any place as part of a working outfit. Skirts not too tight; if slit, the underskirt should be sufficiently long and appropriate. Well-made tailored suits are always suitable and serviceable. Becoming selection and the harmony of colors are necessary to tasteful dress.

Hair: Should be arranged becomingly and simply, without hair ornaments or conspicuous bows.

Cosmetics and perfumes have no connection with business attire.

Jewelry: Very little should be worn, and only such as is in keeping with a working costume, never anything showy or elaborate.

Footwear: Neat, comfortable, serviceable shoes, high or low. Conspicuous hosiery and dress slippers with French heels are in bad taste for working garb.

Hats: Should not exceed "locker space" in size.

Those were the conditions generally prevailing when I entered the trade five years later. Most of the women had achieved miracles of drabness and had the appearance of being, as the saying goes, "settled." The full skirts of some had leaded hems; these automatically dusted the lower shelves; over them, many tied sturdy aprons but wore their reticules on the outside. Those of you who saw Helen Hayes play a she-librarian in Happy Birthday will remember that her dress was described as "meager" and that it was said of her that "the one note of vanity in her entire make-up" was her shoes. Anita Loos may be older than she allows.

The men, in those far-off days, were 
even more subdued, what with their black-cotton coats and paper cuffs. There were exceptions, of course, and among them, Appleton P. C. Griffin, Chief Assistant Librarian of Congress, who was invariably swathed in a cutaway and carried a swagger stick on his walks from his office to the catalog. But when he was succeeded by Fred Ashley, tradition was reasserted.

I give these personal reminiscences only to explain the pleasure I have experienced in witnessing the Revolution. I hope it is here to stay, but I have dim misgivings. Why should not women librarians, with their hard-won victory, continue to be glamorous and lovely and attractive? And why should not men librarians occasionally resemble other men? I, for one, pray that they may. But the forces of opposition are strong and powerful. They are allied with those peasants who suppose that readers come to look at books rather than at librarians. They forget that under the most salutary circumstances librarians are sometimes obliged to gaze on one another. This creates an efficiency factor; an element of cooperation.

I do not, I cannot forget that there have always been those who insist that librarians should be indistinguishable from their charges; that they should be bound rather than clothed. But these outrageous critics do not realize how disturbing crushed morocco can be when gathered about the epidermis, or how cloying is ruby buckram, or in what eccentric formats some librarians are made.

But, alas, I can no longer be sanguine about the situation, no longer phlegmatic, no longer complacent. The Administrators, having settled all the other problems of their so-called science, are beginning to think about costume once again.

Not so long ago, in an eastern institution, the following draft of an order received limited circulation; it I reproduce verbatim:
Subject: Attire for members of the staff who serve the public.

Your attention is called to the need for each staff member who serves the public to present a neat appearance. Individuals who fail to maintain presentable appearance shall be warned.

Effective immediately, members of the staff in all reading rooms and other areas of public service shall be directed that 1) short sleeve sport shirts without ties are not permitted, 2) if galluses are worn, or shirts of transparent material, a coat is required, 3) in hot weather the minimum requirement is a clean long sleeve, white shirt with a tie.

That is the proposed edict; its sinister implications are not, I trust, lost on any one of you. At first glance, it appears to have been perpetrated by a woman, but when one considers the raiment described, one is driven to the realization that these articles are no longer exclusively identifiable with the male. Women, too, are now wearing Polynesian bodices and are enjoying the benefits of décolletage. They, too, are sometimes seen in short sleeves, but who would be so foolish as to maintain that a reader's concentration on his work is less likely to be distracted, diverted, confounded by a lady's lovely fore-arm than by a gentleman's hirsute tattoo. Nonsense, say I, and I implore you to agree.

But permit me, brothers and sisters, to repeat the third injunction: "In hot weather the minimum requirement is a clean long sleeve, white shirt with a tie." It isn't going barefooted that arouses my angry objection. It is being denied the sacred, the guaranteed privileges of pants. Without them, aren't we going to seem even more ridiculous? Won't the sacrifice make us diffident and a little shy? In all solemnity, I cry out to you that we must uphold our trousers-uphold them if need be- to the very end. And so, my hearties, gird up your loins. The battle is joined. Let us chant together that line from Pope: "Who pants for glory finds but short repose." 